\title{
A PRISÃo APÓS SEGUNDA INSTÂNCIA E O PRINCÍPIO DA PRESUNÇÃO DE INOCÊNCIA E NÃO CULPABILIDADE
}

IMPRISONMENT AFTER SECOND INSTANCE AND

THE PRINCIPLE OF PRESUMPTION OF INNOCENCE AND NON-CULPABILITY

Pablo Martins Bernardi COELHO'

ISSUE DOI: $10.21207 / 1983.4225 .825$

\begin{abstract}
RESUMO
O presente trabalho busca discutir o princípio da presunção de inocência e não culpabilidade e a prisão em decorrência de sentença recorrível em segunda instância. Dessa forma, foram realizadas pesquisas históricas das constituições brasileiras e tratados internacionais, jurisprudências relativas à Habeas Corpus analisados pelo Supremo Tribunal Federal, além de pesquisa bibliográfica de autores do direito constitucional e penal. Assim foi possível desencadear raciocínio jurídico em relação ao reflexo das decisões da Suprema Corte e a relevância de princípios constitucionais garantidores de direitos universais. No decorrer do trabalho infere-se a construção do princípio da presunção da inocência no âmbito internacional, em convenções, tratados e declarações, posteriormente o seu desenvolver no ordenamento jurídico brasileiro, levando em consideração os momentos históricos vividos até a consolidação do referido princípio na Constituição Federal de 1988. Fez-se necessário também elencar as prisões cautelares previstas no código de processo penal e que as mesmas estão em consonância com o artigo $5^{\circ}$ inciso LVII da Carta Magna. Por fim foram analisadas decisões do STF e suas consequências jurídicas no que concerne ao impacto causado nos casos concretos.
\end{abstract}

\footnotetext{
${ }^{1}$ Professor Efetivo do Curso de Direito da Universidade do Estado de Minas Gerais (UEMG). Professor do curso de Direito da Faculdade Presidente Antônio Carlos - UNIPAC/Uberlândia. Tem experiência na área de Direito, História e Ciências Sociais, atuando principalmente nos seguintes temas: Direitos Constitucional, Direito Administrativo, Direito Eleitoral, Municipal e Ciência Política. Participa como membro da ALACIP (Associação Latino Americana de Ciência Política). É membro do grupo de pesquisa Laboratório Americano de Estudos Constitucionais Comparados da UFU e líder do grupo de pesquisa Cultura, Direito \& Sociedade da UEMG. É avaliador MEC inserido no Banco de Avaliadores (BASis) do Sistema Nacional de Avaliação da Educação Superior (Sinaes) para os cursos de Direito. Contato: pablo.coelho@uemg.br. http://lattes.cnpq.br/0584374185581812.
} 
Palavras-chave: Presunção de Inocência. Supremo Tribunal Federal. Constituição Federal. Segunda instância.

\begin{abstract}
The present paper seeks to discuss the principle of presumption of innocence and non-culpability and imprisonment as a result of a judgment that can be appealed at second instance. In this way, we have carried out historical surveys of the Brazilian constitutions and international treaties, Habeas Corpus jurisprudence analyzed by the Federal Supreme Court, as well as bibliographical research of authors of constitutional and criminal law. Thus it was possible to initiate legal reasoning in relation to the reflection of Supreme Court decisions and the relevance of constitutional principles guaranteeing universal rights. In the course of the work, it is inferred that the principle of presumption of innocence at the international level, in conventions, treaties and declarations, was developed in the Brazilian legal system, taking into account the historical moments lived until the consolidation of this principle in the Constitution 1988. It was also necessary to list the precautionary prisons provided for in the code of criminal procedure and that they are in accordance with Article 5, item LVII of the Magna Carta. Finally, decisions of the Supreme Court and its legal consequences were analyzed with regard to the impact caused in the concrete cases.
\end{abstract}

Keywords: Presumption of Innocence. Supreme Court. Federal Constitution. Second instance. Legal consequences.

\title{
1 INTRODUÇÃO
}

O presente trabalho tem como objetivo discutir sobre o princípio da não culpabilidade, também denominado presunção de inocência, - previsto no art. $5^{\circ}$, inciso LVII, da Constituição Federal - frente ao recente entendimento jurisprudencial sobre a possibilidade de início de cumprimento de pena após decisão em segunda instância.

A prisão no sistema jurídico brasileiro é possível antes e depois do trânsito em julgado da condenação, porém a primeira somente a título cautelar, ou seja, aquela prisão instrumental que se faz necessária para o andamento do processo, uma garantia da efetividade processual.

A possibilidade de prisão para cumprimento de pena somente após o trânsito em julgado está em consonância com o disposto na Carta Magna no seu artigo $5^{\circ}$ inciso LVII, assim como no artigo 11 da Declaração Universal de Direitos Humanos, onde ambos versam a respeito do princípio da presunção de inocência e da não culpabilidade.

Esse entendimento foi confirmado no HC 84.078-7/09, que tramitou perante o STF, cuja decisão dispõe que a prisão sem sentença penal condenatória, não sendo ela a cautelar, seria inconstitucional.

O sistema carcerário brasileiro está desestruturado, superlotado, além de não estar cumprindo com sua função social, que seria a reabilitação 
do condenado. Ainda assim, a população carcerária cresce desordenadamente e muitos daqueles que estão sob sua custódia não possuem condenação transitada em julgado.

Com o passar do tempo e extensa discussão doutrinária, no ano de 2016, o Supremo Tribunal Federal, no HC 126.292/16, inovou no ordenamento jurídico ao prever que "a execução provisória de acórdão penal condenatório proferido em grau de apelação, ainda que sujeito a recurso especial ou extraordinário, não compromete o princípio constitucional da presunção de inocência afirmado pelo artigo $5^{\circ}$, inciso LVII da Constituição Federal".

Nota-se então que o entendimento fora modificado expondo uma nova realidade de condição de liberdade do acusado, uma vez que uma condenação em segunda instância já seria o suficiente para encarcerá-lo.

Ainda no último entendimento do Supremo, os recursos de caráter extraordinário não são desdobramentos do duplo grau de jurisdição, além de não terem efeitos suspensivos, já que o referido recurso não analisa o mérito, julga apenas no que lhe concerne o direito.

Deste modo, pretende o presente artigo, por meio do método hipotético-dedutivo, responder ao seguinte problema: o entendimento atual do STF, sobre a possibilidade de início de cumprimento de pena de prisão antes do trânsito em julgado fere dispositivos constitucionais referentes à liberdade individual?

Será trabalhada a hipótese afirmativa para a indagação acima, pois há indícios de que diversos direitos fundamentais, tão caros aos seres humanos, estão sendo violados pela decisão da suprema corte brasileira.

Para a verificação da hipótese aventada ao problema, será realizada pesquisa teórica, bibliográfica e consulta jurisprudencial sobre o tema da Presunção de Inocência e a prisão após condenação em segunda instância.

\section{DO PRINCÍPIO DA PRESUNÇÃO DA INOCÊNCIA E NÃO CULPABILIDADE}

O princípio possui como conteúdo essencial servir de argumentação a um direito jusfundamental, diferentemente da regra que é apenas 
uma conduta descritiva, que diz como uma ação deverá ser conduzida. Assim, os princípios podem ser cumpridos em diferentes graus de consecução, e tendem a uma realização e efetividade na maior intensidade possível. Destaca-se o conceito breve de presunção de inocência para Bulos (2015, p. 714):

\begin{abstract}
Somente quando a situação originária do processo for, definitivamente, resolvida é que se poderá inscrever, ou não, o indivíduo no rol dos culpados, porque existe a presunção relativa, ou iuris tantum, da não culpabilidade daqueles que figuram como réus nos processos penais condenatórios.
\end{abstract}

A norma-princípio da Presunção da inocência, a qual foi legalmente prevista pela primeira vez na França no ano de 1789, no artigo $9^{\circ}$ da Declaração dos Direitos do Homem e do Cidadão, logo fora positivada pela Declaração Universal de Direitos Humanos em 1948, em seguida pela Convenção Europeia para a Proteção dos Direitos do Homem e das Liberdades Fundamentais em 1950 e, por fim, pelo Pacto de San Jose da Costa Rica em 1969.

A palavra presunção tem como origem do latim praesumptio, que significa se antecipar, tornar-se antes, ou seja, algo que ainda não aconteceu ou que se espera que aconteça.

Por sua vez, inocência, que também possui origem do latim, innocentia, cujo significado era advindo de práticas religiosas, porém, com o racionalismo iluminista, o termo obteve outros significados e foi inserido no sentido filosófico de um estado ideal a ser conferido ao cidadão.

Na carta Magna de 1988, o princípio da presunção da inocência encontra-se expresso no Artigo $5^{\circ}$, LVII com a seguinte disposição "ninguém será considerado culpado até o trânsito em julgado de sentença penal condenatória". Contudo o autor CretellaJúnior (1990, p. 537), categoricamente ensina o significado de trânsito em julgado como se pode conferir:

\footnotetext{
Somente a sentença penal condenatória, ou seja, a decisão de que não mais cabe recurso, é a razão jurídica suficiente para que alguém seja considerado culpado. (...). Não mais sujeita a recurso, a sentença penal condenatória tem força de lei e, assim, o acusado passa ao status de culpado, até que cumpra a pena, a não ser que revisão criminal nulifique o processo, fundamento da condenação.
}

Desta forma o autor expõe que o trânsito em julgado seria o fato que impede que a decisão seja objeto de recurso, seja por ter extinguido o prazo para recorrer ou por já ter sido esgotado os tipos recursais existentes, 
portanto conclui-se que enquanto pendente qualquer recurso não há o que se falar em iniciar o cumprimento da sentença penal condenatória.

\section{DAS PRISÕES CAUTELARES NO PROCESSO PENAL BRASILEIRO.}

O princípio da presunção da inocência ou não culpabilidade se encontra em perfeita conformidade no que diz respeito às prisões, as quais são um direito estatal de garantir a eficácia da persecução penal evitando o periculum in mora, em busca da justiça e proteção social.

Assim, o código de processo penal discorre sobre as possibilidades de aplicação dessa medida. A liberdade do indivíduo é a regra, porém há situações que autorizam o recolhimento de autores de infração penal, antes de sua condenação, sendo elas as prisões cautelares, as quais são derivadas de regras de cunho processual, com o intuito de resguardar a própria persecução penal em seu trâmite regular.

As hipóteses de tais prisões, sendo elas a em flagrante delito previsto no artigo 302 do Código de Processo Penal, a prisão preventiva disposta no artigo 321 e 313 do mesmo código e a prisão temporária prevista em Lei específica $n^{\circ} 7.960 / 89$. Em todos os casos serão observados o caráter de urgência ou quando não for cabível outra medida cautelar diversa da prisão.

As prisões contidas no código de processo penal, diferentemente das sanções trazidas pelo código civil que tem caráter punitivo na seara patrimonial, incidem diretamente no direito de locomoção do indivíduo, incidindo a pena sobre seu próprio corpo.

Há uma classificação doutrinária no que diz respeito à prisão, podendo ela ser dividida em prisão-pena, sendo aquela que satisfaz o jus puniendi, que significa segundo Fernando Capez (2012, p.45) "O Estado, única entidade dotada de poder soberano, é o titular exclusivo do direito de punir (para alguns, poder-dever de punir) (...)", ou seja, aquela decorrente de sentença penal condenatória transitada em julgado. E a prisão sem pena, a qual não decorre de sentença penal condenatória transitada em julgado, também conhecida como prisão cautelar, processual ou provisória, de caráter excepcional, uma vez que estamos sob a égide do artigo $5^{\circ}$ inciso LVII da Constituição Federal. 


\section{POSICIONAMENTO DO STF EM RELAÇÃO À PRISÃO APÓS A CONDENAÇÃO EM SEGUNDA INSTANCIA.}

A presunção da inocência ou não culpabilidade prevista no artigo $5^{\circ}$ inciso LVII da Constituição Federal, como já dito anteriormente dispõe que ninguém poderá ser considerado culpado até sentença penal condenatória transitada em julgado, salvo nos casos já previstos no código de processo penal, as já elencadas prisões cautelares. No ano de 2009 o Supremo Tribunal Federal (STF) foi acionado a pacificar tal entendimento sobre a possibilidade de o acórdão condenatório proferido em segunda instância ser o marco inicial do cumprimento de pena em caráter de mérito.

O caso que deu ensejo a discussão ocorreu na cidade de Passos/MG onde o réu Omar Coelho Vitor, condenado em segunda instância pelo crime de tentativa de homicídio qualificado, com pena de sete anos e seis meses de reclusão, impetrou recurso especial no Superior Tribunal de Justiça, porém o Ministério Público, antes mesmo de analisado o recurso requereu a prisão para cumprimento de pena de Omar ao Tribunal de Justiça de Minas Gerais, sendo deferido seu pedido.

Decretada a prisão o réu, e ainda sem uma decisão do STJ, impetrou habeas corpus no Supremo Tribunal Federal, juntamente com o pedido da suspensão da execução da pena, pedindo a desconsideração do artigo 637 do código penal com a seguinte redação: "O recurso extraordinário não tem efeito suspensivo, e uma vez arrazoados pelo recorrido os autos do traslado, os originais baixarão à primeira instância, para a execução da sentença". O HC 84078 foi julgado pela segunda turma da Corte Suprema e teve como relator o ministro Eros Roberto Grau.

O referido Habeas Corpus gerou grandes debates com posicionamentos fundamentados a favor e contra o início do cumprimento da pena com a condenação do TJ/MG, porém por sete votos a quatro foi concedido, deferido o Habeas Corpus pautado principalmente no principio fundamental da presunção da inocência, como já dito reiterada vezes nesse trabalho que além de um principio constitucional, se trata de um preceito constante em documentos internacionais dos quais o Brasil é signatário. Segue trecho da ementa do HC de 2009:

HABEAS CORPUS. INCONSTITUCIONALIDADE DA CHAMADA"EXECUÇÃO ANTECIPADA DA PENA". ART. 5', LVII, DA CONSTITUIÇÃODO BRASIL. DIGNIDADE DA PESSOA HUMANA. ART. $1^{\circ}$, III, DACONSTITUIÇÃO DO BRASIL. 1. O art. 637 do CPP estabelece que "[o] recurso extraordinário 
não tem efeito suspensivo, uma vez arrazoados pelo recorrido os autos do traslado, os originais baixarão à primeira instância para a execução da sentença". A Lei de Execução Penal condicionou a execução da pena privativa de liberdade ao trânsito em julgado da sentença condenatória. A Constituição do Brasil de 1988 definiu, em seu art. $5^{\circ}$, inciso LVII, que "ninguém será considerado culpado até o trânsito em julgado de sentença penal condenatória". 2. Daí que os preceitos veiculados pela Lei n. 7.210/84, além de adequados à ordem constitucional vigente, sobrepõem-se, temporal e materialmente, ao disposto no art. 637 do CPP. 3. A prisão antes do trânsito em julgado da condenação somente pode ser decretada a título cautelar. 4. A ampla defesa, não se a pode visualizar de modo restrito. Engloba todas as fases processuais, inclusive as recursais de natureza extraordinária. Por isso a execução da sentença após o julgamento do recurso de apelação significa, também, restrição do direito de defesa, caracterizando desequilíbrio entre a pretensão estatal de aplicar a pena e o direito, do acusado, de elidir essa pretensão. [...] 6. A antecipação da execução penal, ademais de incompatível com o texto da Constituição, apenas poderia ser justificada em nome da conveniência dos magistrados --- não do processo penal. A prestigiar-se o princípio constitucional, dizem, os tribunais [leiase STJ e STF] serão inundados por recursos especiais e extraordinários e subsequentes agravos e embargos, além do que "ninguém mais será preso". Eis o que poderia ser apontado como incitação à "jurisprudência defensiva", que, no extremo, reduz a amplitude ou mesmo amputa garantias constitucionais. A comodidade, a melhor operacionalidade de funcionamento do STF não pode ser lograda a esse preço. [...]8. Nas democracias mesmo os criminosos são sujeitos de direitos. Não perdem essa qualidade, para se transformarem em objetos processuais. São pessoas, inseridas entre aquelas beneficiadas pela afirmação constitucional da sua dignidade. (art. $1^{\circ}$, III, da Constituição do Brasil). É inadmissível a sua exclusão social, sem que sejam consideradas, em quaisquer circunstâncias, as singularidades de cada infração penal, o que somente se pode apurar plenamente quando transitada em julgado a condenação de cada qual Ordem concedida. (STF, 2009)

Conforme exposto na ementa do HC 84078, os argumentos utilizados para concessão do habeas corpus, além do princípio da presunção de inocência, os julgadores pautaram em outro direito fundamental também previsto no artigo $5^{\circ}$ da Constituição federal inciso LV, o principio da ampla defesa e contraditório, tendo em vista que iniciar-se o cumprimento da pena antes do transito em julgado de sentença penal condenatória cercearia o direito de defesa do réu, podendo constatar uma mitigação a direitos fundamentais.

O ministro Gilmar Mendes que também votou a favor da concessão do habeas corpos mostrou ainda outra ótica a respeito do encarceramento exacerbado que ocorre no país e a quem estaria beneficiando a prisão com condenação em segunda instância e qual grupo social estaria sendo 
atingido com a limitação de uma garantia fundamental, em um trecho dos debates ele explana:

Eu tenho dados, decorrentes da atividade no Conselho Nacional de Justiça, que são impressionantes. Apesar dessa inefetividade, o Brasil tem um índice bastante alto de presos. São quatrocentos e quarenta mil presos (dados de 2008), dos quais cento e oitenta e nove mil presos provisórios. Muitos deles há mais de dois, há mais de três anos, conforme se tem encontrado nesses mutirões do Conselho Nacional de Justiça. Portanto, se nós formos olhar por Estados, a situação é ainda mais grave. Nós vamos encontrar alguns Estados com oitenta por cento dos presos nesse estágio provisório. Nos mutirões realizados pelo Conselho Nacional de Justiça, encontraram-se presos, por exemplo, no Estado do Piauí, que estavam em números muito expressivos - há mais de três anos presos, provisoriamente, sem denúncia apresentada. No Estado do Piauí, há até uma singularidade. O Secretário de Segurança ou a Secretaria de Segurança do Estado do Piauí concebeu um "inquérito de capa preta", significando que a Polícia diz para a Justiça que não deve soltar aquela pessoa. É um mundo de horrores a Justiça criminal brasileira, muitas vezes com a conivência da Justiça e do Ministério Público. [...] Penso que há proposta nesse sentido, no sentido de redimensionar a ideia da prisão preventiva, inclusive para torná-la mais precisa, porque, obviamente, vê-se que há um abuso da prisão preventiva. O Ministro Celso tem liderado, na Turma, nesse sentido. Lembro-me de lições quanto, por exemplo, aos crimes de bagatela- em geral se encontram pessoas presas no Brasil porque furtaram uma escova de dente, um chinelo, coisas assim. Portanto, não se cumpre minimamente aquilo que foi citado pela Ministra Ellen Gracie, aquela comunicação feita ao juiz para que ele atenda ou observe os pressupostos da prisão preventiva. A prisão em flagrante só deve ser mantida se de fato estiverem presentes os pressupostos da prisão preventiva, do contrário o juiz está obrigado, por força constitucional, a relaxar. Estou absolutamente certo de que esta é uma decisão histórica e importante do Tribunal. Por outro lado, eu tenho a impressão - e faço aqui algumas considerações, conforme já fiz em outro momento - de que nós estamos nesse processo permanente de transição, especialmente no Direito Constitucional. (STF, 2009)

Entende-se, portanto que criar outra modalidade de prisão, com a antecipação do cumprimento da pena não solucionaria o problema, pois, como demonstrou o Exmo. Ministro, o sistema carcerário brasileiro está superlotado e muitos dos detentos não possuem sequer qualquer julgamento do seu caso, fica claro o entendimento em que a restrição da liberdade atinge em sua maioria a classe mais desfavorecida economicamente, sem o mínimo de dignidade humana e demais garantias fundamentais. Assim a ausência de decisão condenatória transitada em julgado jamais deverá antecipar a aplicação da sanção. 
Acerca disso, o Ministro Ricardo Lewandowski em um recurso extraordinário RE 482.006/MG que foi citado pelo Ministro Eros Grau no $\mathrm{HC}$ em tela, diz a respeito da Lei estadual do Estado de Minas Gerais (Lei 2.364/61), a qual autoriza a redução dos vencimentos de servidores públicos processados criminalmente, sendo esse indeferido uma vez que claramente fere o principio constitucional da presunção da inocência, posto que não foi observado o devido processo legal, além de uma antecipação de uma sansão sem uma condenação propriamente dita, tal entendimento foi unânime perante a corte. Cabe salientar em uma analogia simples que o Supremo em se tratando de direito de propriedade não hesitou em reconhecer a inconstitucionalidade da antecipação da pena, porém quando a garantia fere a liberdade o preceito constitucional, esse último deveria ser analisado de forma diversa, relativizada. Conforme consta no relatório do $\mathrm{HC}$ 84078:

Devo manifestar, por fim, certeza e absoluta segurança em que esta Corte prestará o devido acatamento à Constituição. E faço referência, a propósito, não apenas a decisões atinentes à afirmação da liberdade, mas a outra, bem recente, de 7 de novembro de 2.007. Desejo aludir ao RE 482.006, relator o Ministro Lewandowski, quando foi debatida a constitucionalidade de preceito de lei estadual mineira que impõe a redução de vencimentos de servidores públicos afastados de suas funções por responderem a processo penal em razão da suposta prática de crime funcional [art. $2^{\circ}$ da Lei n. 2.364/61, que deu nova redação à Lei n. 869/52]. Decidiu-se então, por unanimidade, que o preceito implica flagrante violação do disposto no inciso LVII do art. $5^{\circ}$ da Constituição do Brasil. Isso porque --- disse o relator --- "a se admitir a redução da remuneração dos servidores em tais hipóteses, estar-se-ia validando verdadeira antecipação de pena, sem que esta tenha sido precedida do devido processo legal, e antes mesmo de qualquer condenação, nada importando que haja previsão de devolução das diferenças, em caso de absolvição". Daí porque a Corte decidiu, por unanimidade, sonoramente, no sentido do não recebimento do preceito da lei estadual pela Constituição de 1.988. Afirmação unânime, como se vê, da impossibilidade de antecipação de qualquer efeito afeto à propriedade, anteriormente ao seu trânsito em julgado, a decisão com caráter de sanção. Ora, a Corte que vigorosamente prestigia o disposto no preceito constitucional em nome da garantia da propriedade certamente não o negará quando se trate da garantia da liberdade. Não poderá ser senão assim, salvo a hipótese de entender-se que a Constituição está plenamente a serviço da defesa da propriedade, mas nem tanto da liberdade... Afinal de contas a propriedade tem mais a ver cora as elites; a ameaça às liberdades alcança de modo efetivo as classes subalternas. Concedo a ordem para determinar que o paciente aguarde em liberdade o trânsito em julgado da sentença condenatória. (STF, 2009) 
Os votos vencidos, ora contrários a concessão do HC 84078, capitaneados pelo Ministro Joaquim Barbosa elucidou em seu voto os motivos pelos quais a corte deveria entender pelo cumprimento da pena com decisão proferida em segunda instância, conforme trecho do seu voto que diz:

Adotar a tese de que somente com o trânsito em julgado da condenação poderia haver execução penal causará verdadeiro estado de impunidade - considerando a sobrecarga já consolidada do Poder Judiciário, e em especial dessa Suprema corte -, especialmente para aquele sentenciado que disponha a seu favor de defensor cujo fim precípuo seja utilizar-se do maior número possível e imaginável de recursos (e nisto o nosso ordenamento é rico), de molde a estender eternamente o trânsito em julgado do provimento condenatório, situação que em não poucos casos acaba por impor o reconhecimento da prescrição da pretensão executória, frustrando o direito fundamental à tutela jurisdicional efetiva, o respeito à vitima e também à própria atuação e trabalho do Poder Judiciário, que findaria por ser nula no fim das contas. Veja-se que não se trata de relegar à inoperância o princípio da presunção de inocência do acusado, mas se estará a velar pelo cumprimento provisório de provimento condenatório, já exaustivamente decidido nas instâncias ordinárias. Volto a frisar as instâncias competentes para exame dos fatos. Ora, o princípio do estado de inocência não é absoluto e incontrastável em nosso ordenamento jurídico; foi com base na sua ponderação que, por exemplo, esta Corte sempre entendeu e continua entendendo legítimos os institutos da prisão preventiva e da prisão temporária. Relativamente ao condenado, a execução provisória da pena também é de ser admitida, considerada não a culpa inconteste do réu, mas a existência de decisões judiciais condenatórias, calcadas nos exames dos fatos, que tornam legítima a privação da sua liberdade. (STF, 2009)

O ministro Joaquim Barbosa deixa claro que a execução provisória da pena não feriria o principio constitucional da presunção da inocência, uma vez que este principio não é absoluto, além de frisar que com a quantidade de recursos cabíveis o processo jamais chegaria a seu fim, se tornando ineficaz, além de defender a legitimidade das instâncias ordinárias, as quais proferem decisões condenatórias dotadas de efetividade, afinal analisa a matéria de fato. Ao final o referido ministro reitera o pedido para denegação do HC em estudo:

Por fim, deve-se considerar que os fins da pena, de prevenção geral e especial, ficarão completamente perdidos se aguardar toda a infinidade de recursos que podem ser interpostos pela defesa para dar execução ao decreto condenatório. Com efeito, o transcurso do tempo desde os fatos até o cumprimento da pena faz com que se perca a memória dos motivos que tornam necessária a reprimenda 
penal. Assim, impede-se a real socialização do apenado e prejudica-se a percepção da necessidade da pena para a vida em uma sociedade ordeira e pacífica. Por todo o exposto, Senhor Presidente, meu voto, na hipótese, é pela denegação da ordem, admitindo a execução provisória da pena uma vez exauridas as instâncias ordinárias. (STF, 2009)

No ano de 2016 o Supremo Tribunal Federal foi provocado novamente a respeito da possibilidade de iniciar-se a execução da pena com sentença condenatória de segunda instância frente ao princípio da presunção de inocência, o caso ocorreu em São Paulo/SP, quando um ajudante geral chamado Márcio Rodrigues Dantas foi condenado à pena de 05 anos e 04 meses de reclusão pelo crime de roubo qualificado. Depois da condenação em primeiro grau, a defesa recorreu ao TJ-SP, que negou provimento ao recurso e determinou a expedição de mandado de prisão.

Assim, com o indeferimento liminar do HC no STJ o recurso foi analisado pela Suprema Corte que agindo contrária a própria jurisprudência consolidada no ano de 2009 (HC 84078) denegou o pedido sobre o argumento que a manutenção da sentença penal pela segunda instância encerra a análise de fatos e provas que assentaram a culpa do condenado, autorizando assim o início da execução da pena, ou seja, a antecipação da pena.

O Supremo decidiu por sete votos a quatro pela possibilidade do cumprimento da pena após decisão de acórdão judicial, sem prejuízos ao principio fundamental da presunção de inocência, uma vez que o tribunal julga matéria de fato e provas, já os recursos ordinários e extraordinários julgam apenas no que concerne o direito, além de não possuir caráter suspensivo, assim o réu na persecução penal, ou seja, no processo criminal ordinário teve assegurado sua garantia fundamental, ampla defesa e contraditório, conforme exposto no voto do ministro relator Teori Zavascki, in verbis:

O tema relacionado com a execução provisória de sentenças penais condenatórias envolve reflexão sobre (a) o alcance do princípio da presunção da inocência aliado à (b) busca de um necessário equilíbrio entre esse princípio e a efetividade da função jurisdicional penal, que deve atender a valores caros não apenas aos acusados, mas também à sociedade, diante da realidade de nosso intricado e complexo sistema de justiça criminal. 3. A possibilidade da execução provisória da pena privativa de liberdade era orientação que prevalecia na jurisprudência do STF, mesmo na vigência da Constituição Federal de 1988. Nesse cenário jurisprudencial, em caso semelhante ao agora sob exame, esta Suprema Corte, no julgamento do HC 68.726 (Rel. Min. Néri da Silveira), realizado em 28/6/1991, 
assentou que a presunção de inocência não impede a prisão decorrente de acórdão que, em apelação, confirmou a sentença penal condenatória recorrível. [...] Ao reiterar esses fundamentos, o Pleno do STF asseverou que, "com a condenação do réu, fica superada a alegação de falta de fundamentação do decreto de prisão preventiva", de modo que "os recursos especial e extraordinário, que não têm efeito suspensivo, não impedem o cumprimento de mandado de prisão" (HC 74.983, Rel. Min. Carlos Velloso, julgado em 30/6/1997). [...] Realmente, a execução da pena na pendência de recursos de natureza extraordinária não compromete o núcleo essencial do pressuposto da não-culpabilidade, na medida em que o acusado foi tratado como inocente no curso de todo o processo ordinário criminal, observados os direitos e as garantias a ele inerentes, bem como respeitadas as regras probatórias e o modelo acusatório atual. Não é incompatível com a garantia constitucional autorizar, a partir daí, ainda que cabíveis ou pendentes de julgamento de recursos extraordinários, a produção dos efeitos próprios da responsabilização criminal reconhecida pelas instâncias ordinárias. Nessa trilha, aliás, há o exemplo recente da Lei Complementar 135/2010 (Lei da Ficha Limpa), que, em seu art. $1^{\circ}$, I, expressamente consagra como causa de inelegibilidade a existência de sentença condenatória por crimes nela relacionados quando proferidas por órgão colegiado. É dizer, a presunção de inocência não impede que, mesmo antes do trânsito em julgado, o acórdão condenatório produza efeitos contra o acusado. (STF, 2016)

O ministro Teori Zavascki, ressaltou argumentos utilizados no HC 84078, no que diz respeito à prolação para iniciar o cumprimento da pena com a quantidade de recursos oferecida ao réu e citou a ministra aposentada Ellen Graice que se manifestou no julgamento do HC 85886 da seguinte forma: "em país nenhum do mundo, depois de observado o duplo grau de jurisdição, a execução de uma condenação fica suspensa aguardando referendo da Suprema Corte". Da mesma forma, os ministros Edson Fachin, Luís Roberto Barroso, Luiz Fux, Dias Toffoli, Cármen Lúcia e Gilmar Mendes, acompanharam o relator pelo indeferimento do pleito.

O ministro Ricardo Lewandowski que participou do plenário de ambos os Habeas Corpus (84078 e 126292) manteve sua posição, ratificando que a antecipação do cumprimento da pena fere o principio constitucional da presunção da inocência, ressalvados os casos de prisão cautelar, e ainda cita o sistema prisional falido vigente, o qual não cumpre sua função social, e encarcerar mais pessoas não estaria visando uma solução justa e eficaz. Assim dispõe o voto do referido ministro:

Eu vou pedir vênia ao eminente Relator e manter a minha posição, que vem de longa data, no sentido de prestigiar o princípio da presunção de inocência, estampado, com todas as letras, no art. $5^{\circ}$, in- 
ciso LVII, da nossa Constituição Federal. Assim como fiz, ao proferir um longo voto no HC 84.078, relatado pelo eminente Ministro Eros Grau, eu quero reafirmar que não consigo, assim como expressou o Ministro Marco Aurélio, ultrapassar a taxatividade desse dispositivo constitucional, que diz que a presunção de inocência se mantém até o trânsito em julgado. Isso é absolutamente taxativo, categórico; não vejo como se possa interpretar esse dispositivo. Voltando a, talvez, um ultrapassadíssimo preceito da antiga escola da exegese, eu diria que in claris cessat interpretatio. E aqui nós estamos, evidentemente, in claris, e aí não podemos interpretar, data venia. [...] Eu também, respeitosamente, queria manifestar a minha perplexidade desta guinada da Corte com relação a esta decisão paradigmática, minha perplexidade diante do fato de ela ser tomada logo depois de nós termos assentado, na ADPF 347 e no RE 592.581, que o sistema penitenciário brasileiro está absolutamente falido. E mais, nós afirmamos, e essas são as palavras do eminente Relator naquele caso, que o sistema penitenciário brasileiro se encontra num estado de coisas inconstitucional. Então, agora, nós vamos facilitar a entrada de pessoas neste verdadeiro inferno de Dante, que é o nosso sistema prisional? Ou seja, abrandando esse princípio maior da nossa Carta Magna, uma verdadeira cláusula pétrea. Então isto, com todo o respeito, data venia, me causa a maior estranheza. Eu queria dizer também, sempre atento, não apenas à literatura jurídica, estritamente, que é o nosso dever conhecê-la com maior profundidade, mas também atento à leitura dos historiadores e dos sociólogos brasileiros, eu vejo e constato isso, e vou elaborar um pouco sobre esse argumento, que, em nossa história, a propriedade sempre foi um valor que se sobrepôs ao valor liberdade. [...] O crime de furto e o crime de roubo são muitíssimo mais apenados ou apenados com penas bem maiores do que o crime de lesão corporal, por exemplo, ou o crime contra a honra a calúnia, a difamação, a injúria. São penas insignificantes se nós considerarmos que a pena mínima de furto é de dois anos, e do roubo é de quatro anos. Ou seja, no Brasil, o sistema jurídico sempre deu maior valor à propriedade. Antes mesmo que o Ministro Marco Aurélio fizesse alusão à disparidade de tratamento que o nosso sistema jurídico dá no que diz respeito à execução provisória, à propriedade e à liberdade, eu fazia aqui uma consulta - e eu externo meu pensamento com muita reverência, e até com certo temor, diante do grande especialista no Código de Processo Civil, que é o Ministro Fux, um dos principais elaboradores do novo Código do Processo Civil -, mas eu verifiquei aqui, e confirmando aquilo que o Ministro Marco Aurélio acaba de afirmar, que o art. 520 do novo CPC estabelece que:"Art. 520. (...) IV. o levantamento de depósito em dinheiro" - vil metal - "e a prática de atos que importem transferência de posse ou alienação de propriedade ou de outro direito real, ou dos quais possa resultar grave dano ao executado, dependem de caução suficiente e idônea, arbitrada de plano pelo juiz e prestada nos próprios autos". E vem aquilo ao qual o Ministro Marco Aurélio aludiu, diz o art. 520, II: "Art. 520. (...) II. fica sem efeito, sobrevindo decisão que modifique ou anule a sentença objeto da execução" - claro, a transferência do bem, a propriedade - "restituindo-se as partes ao estado anterior e liquidando-se 
eventuais prejuízos nos mesmos autos". Ora, em se tratando de dinheiro de propriedade, o legislador pátrio se cercou de todos os cuidados para evitar qualquer prejuízo, a restituição integral do bem, no caso de reversão de uma sentença posterior, por parte do Tribunais Superiores. (STF, 2016)

Perante toda discussão jurisprudencial a respeito do Supremo Tribunal Federal frente ao principio da presunção da inocência do artigo $5^{\circ}$ inciso LVII, verifica-se que o guardião da Constituição Federal ao relativizar garantia fundamental causa prejuízo no que concerne a culpa do acusado, mitigando sua ampla defesa e o estigmatizando perante a sociedade civil.

É percebido que o STF ao solidificar entendimento acerca da antecipação na execução da pena tende a demonstrar uma punição efetiva do poder judiciário, mesmo tendo conhecimento do sistema carcerário falido que temos atualmente, afim de uma manutenção falsa do status quo, ferindo direitos e garantias individuais conquistadas a longos anos.

Assim a Presunção de inocência, como bem observa Lima (2014):

A presunção de inocência é reconhecida hoje como um direito universal do indivíduo, decorrente da dignidade humana que possui, de modo que qualquer afronta à dimensão denominada "mínimo ético irredutível", importa violação dos direitos humanos que lhe são garantidos.

Não cabe assim a Suprema Corte interpretar de forma leviana um preceito constitucional de tamanha relevância e taxatividade com a intenção de que se resolva a criminalidade no país e a não impunidade, o encarceramento antes do transito em julgado só penaliza o acusado por uma ineficiência do poder judiciário de exprimir decisões dentro da duração razoável do processo legal.

\section{CONSIDERAÇÕES FINAIS}

Diante de todo exposto pode ser verificado que o princípio da presunção de inocência e não culpabilidade, previsto no inciso LVII do artigo $5^{\circ}$ da Constituição Federal é uma garantia individual e fundamental, 
portanto cláusula pétrea em nosso ordenamento jurídico vigente. Esse princípio ainda está consolidado em tratos internacionais, que versa sobre direitos humanos, dos quais o Brasil é signatário.

Contudo, com o processo histórico da formação das constituições brasileiras e a complexidade do sistema de justiça criminal surgiu a necessidade de se discutir tal princípio, a fim de analisar o esgotamento da inocência, assim por dizer até em que momento o réu deverá ser considerado inocente na persecução penal.

Assim, o Supremo Tribunal Federal em seu Habeas Corpus 84.078 exprimiu pela maioria dos votos que o réu condenado em segunda instância não poderia iniciar seu cumprimento da pena, uma vez que se trataria de antecipação da execução da pena, tendo em vista que o cabimento de recursos ordinário e extraordinário seria tempestivo. Destarte que se aplicando a antecipação da sanção estaria ferindo diretamente o preceito constitucional objeto desse estudo.

No ano de 2016 o STF ao julgar o HC 126.292, foi totalmente contrário a jurisprudência anteriormente já pacificada, denegando a concessão de habeas corpus com fundamento de que decisão de acórdão penal poderia encarcerar o réu, tendo em vista que a condenação em segunda instância analisa matéria de fato e direito, não sendo necessário qualquer referendo do Supremo para a aplicação da pena.

O presente trabalho ao discutir os diferentes posicionamentos do Supremo Tribunal Federal, inferiu que é claro e evidente a transgressão ao princípio da presunção de inocência disposto na Carta Magna de 1988, sendo que a relativização de uma garantia fundamental causa imensa instabilidade e insegurança jurídica.

A suprema Corte tem por principal objetivo ser o guardião da Constituição Federal que a protege de qualquer instabilidade da opinião pública ou política, portanto a garantia constitucional da presunção de inocência deve valer-se mais do que a mera discussão processualística de efeitos recursais e seu efeito não suspensivo.

As prisões cautelares previstas na lei infraconstitucional preveem as possibilidades da prisão antes do transito em julgado de sentença penal condenatória, se preenchidos os requisitos nela elencados, assim não há o que se falar em criar outra modalidade de prisão, qual seja aquela após condenação em segunda instância, portanto o entendimento do Supremo que está em vigor se equivoca em relação à execução provisória da pena. 
O encarceramento exacerbado é notório e consensual no sistema prisional, a criação de outra hipótese de prisão, além das já previstas não solucionaria o problema, tendo em vista que grande parte dos aprisionados não possuem sequer sentença de primeiro grau, assim a superlotação de presídios, pelo óbvio pela população mais carente e negra é reflexo de um sistema judiciário lento e que não primazia pela regra que é a liberdade.

A antecipação da execução da pena por condenação de segundo grau, além de ferir o princípio objeto desse trabalho, lesiona diretamente o princípio da dignidade da pessoa humana, uma vez que o réu que é encarcerado sem uma sentença penal condenatória transitada em julgado, poderá ser absolvido pela instância superior causando-lhe uma desnecessidade ocupacional da prisão, além de uma instabilidade jurídica que refletirá em toda a sociedade.

Dessa forma, conclui-se então que o principio constitucional da presunção da inocência e não culpabilidade decorrente da dignidade da pessoa humana não deve ser refreada por interpretações de juízes e/ou ministros para que não haja uma ameaça a um retrocesso institucional, portanto a culpa presumida antes da sentença penal condenatória transitada em julgado feriria o estado Democrático de Direito, assim por dizer a Lei Maior.

Após a discussão acerca do tema, especificamente ao analisar o HC 84.078 e 126.296, posiciona-se pela inconstitucionalidade da antecipação da execução da pena em segundo grau, posto que como já abordado fere diretamente os princípios constitucionais norteadores do ordenamento jurídico brasileiro indo de encontro ao constituinte originário, legislando ao deliberar jurisprudência que versa violação sobre matéria de cláusula pétrea.

\section{REFERÊNCIAS BIBLIOGRÁFICAS}

BRASIL. Supremo Tribunal Federal. Notícias STF, Disponível em <www.stf.jus.br/portal/cms> acessado em 09 de nov. de 2018.

BULOS, U. L. Curso de direito constitucional. 9. ed. São Paulo: Saraiva, 2015.

CRETELLA JÚNIOR, José. Comentários à Constituição Brasileira de 1988, V. I. Rio de Janeiro: Forense Universitária, 1990. v. I.

CAPEZ, Fernando Curso de processo penal. - 23. ed. - São Paulo: Saraiva, 2016. 
GARCEZ, William. A presunção de inocência na visão do STF: o julgamento do he 126.292. disponível em: <www.jusbrasil.com.br> acesso em: 22 de jun. 2018.

PRODANOVE, Cleber Cristiano; FREITAS, Ernani Cesar. Metodologia doTrabalho científico. $2^{\mathrm{a}}$ Ed. Novo Hamburgo: Feevale, 2013.

SILVA, Walber Carlos da. O princípio da presunção de inocência ou não culpabilidadedisponível em: <www.jus.com.br.>. acesso em: 20 jun. 2018.

STF - HC: 84078/ MG, Relator: Min. EROS GRAU, Data de Julgamento: 05/02/2009, Tribunal Pleno, Data de Publicação: DJe-035 DIVULG 25-02-2010 PUBLIC 26-02-2010 EMENT VOL02391-05 PP-01048.

STF -HC 126292, Relator(a): Min. TEORI ZAVASCKI, Tribunal Pleno, julgado em 17/02/2016, processo eletrônico DJe-100 DIVULG 16-05-2016 PUBLIC 17-05-2016.

TÁVORA, Nestor. Curso de direito processual penal/ Nestor Távora, Rosmar Rodrigues Alencar 12. ed.- Salvador: Ed. JusPodivm. 2017. 